\title{
Production of drinking water using a multi-barrier approach integrating nanofiltration: A pilot scale study
}

\author{
Mafalda Pessoa Lopes ${ }^{\mathrm{a}}$, Cristina T. Matos ${ }^{\mathrm{b}}$, Vanessa J. Pereira ${ }^{\mathrm{a}, \mathrm{d}}$, Maria João Benoliel ${ }^{\mathrm{c}}$, \\ Maria Ermelinda Valério ${ }^{c}$, Luís B. Bucha ${ }^{c}$, Alexandre Rodrigues ${ }^{c}$, Ana I. Penetra ${ }^{c}$, Elisabete Ferreira ${ }^{c}$, \\ Vítor Vale Cardoso ${ }^{c}$, Maria A.M. Reis ${ }^{a}$, João G. Crespo ${ }^{\mathrm{a}, *}$ \\ ${ }^{a}$ CQFB/REQUIMTE, Departamento de Química, FCT, Universidade Nova de Lisboa, P-2829-516 Caparica, Portugal \\ ${ }^{\mathrm{b}}$ Laboratório Nacional de Energia e Geologia, I.P., Unidade de Bioenergia, Estrada do Paço do Lumiar, 22, 1649-038 Lisboa, Portugal \\ ${ }^{\mathrm{c}}$ Empresa Portuguesa das Águas Livres, S.A., Avenida de Berlim, 15, 1800-031 Lisboa, Portugal \\ ${ }^{\mathrm{d}}$ Instituto de Biologia Experimental e Tecnológica (IBET), Av. República, Qta. Do Marquês (EAN), 2784-505 Oeiras, Portugal
}

\section{A R T I C L E I N F O}

\section{Article history:}

Received 17 June 2013

Received in revised form 30 August 2013

Accepted 2 September 2013

Available online 12 September 2013

\section{Keywords:}

Surface water treatment

Nanofiltration

Fouling analysis

UV photolysis

Drinking water production

\begin{abstract}
A B S T R A C T
A multi-barrier system was studied for the production of drinking water with high chemical and microbiological quality. The integration of nanofiltration (NF) and ultraviolet (UV) photolysis was tested at pilot scale in a surface water treatment plant.

The NF membranes tested, Desal DK and NF270, allow for the production of permeates with high quality standards, although the membrane with higher molecular weight cut-off (NF270) revealed to be the best option for surface water treatment due to its higher permeability. The NF270 membrane was also efficient to deliver high quality water, even under high pollutant concentrations, making possible to operate with water recovery rates as high as $98 \%$.

Extensive studies were performed in the water treatment plant where the proposed system was tested at three locations of the drinking water production line. Seeking to achieve the best compromise between high recovery rate, high retention of chemicals and microorganisms as well as preventing operational problems (flux decline and fouling), it was found that the integrated system should be placed after the conventional sand filtration, operating at a $91 \%$ recovery rate. Under the selected conditions - TMP of 8 bar and recovery rate of $91 \%$ - it is possible to operate at constant permeability without flux decline for a period of 15 days, after which a gentle CIP procedure is recommended.

Membrane fouling was also investigated and the major foulant classes identified were proteins, polysaccharides and humic acids. A cleaning protocol was also tested and the impact of each cleaning step on the recovery of permeability evaluated.
\end{abstract}

(c) 2013 Elsevier B.V. All rights reserved.

\section{Introduction}

Drinking water legislation requires a tight control of the water quality for human consumption in order to assure adequate public health conditions [1]. Quality parameters include microbiological parameters, chemical parameters, and other indicator parameters (e.g. total organic carbon, turbidity, and colour). There is a growing interest of water providers and researchers to find solutions to increase the chemical and microbiological quality of the drinking water produced, anticipating future regulations that will include new micro pollutants (e.g. pesticides), which are currently being studied for their potential adverse health effects, even when present in the aquatic environment at extremely low concentrations. Pesticides are intentionally used to control pests. However, their

\footnotetext{
* Corresponding author. Tel./fax: +351212948 385.

E-mail address: jgc@fct.unl.pt (J.G. Crespo).
}

toxic action is not specific to the target organisms and they are toxic to many non-target species, including humans [2].

Conventional surface water treatment often includes screening, coagulation/flocculation, sedimentation, sand filtration, and final disinfection which is often achieved by chlorination. However, such treating systems may not be sufficient to retain the new micro pollutants of concern. Additionally, the use of high quantities of chlorine may induce the formation of disinfection by-products, which are harmful to human health. In this work a multibarrier treatment system is proposed by introducing a combined process with nanofiltration and low pressure UV radiation in a conventional surface water treatment plant. Both treatment processes have shown promising results at independent laboratory scale studies [3-6].

One of the first nanofiltration plants for treating surface water was constructed in Méry-sur-Oise, France, with a capacity of $140,000 \mathrm{~m}^{3} / \mathrm{d}$ [7]. This plant shows high efficiency for the removal 